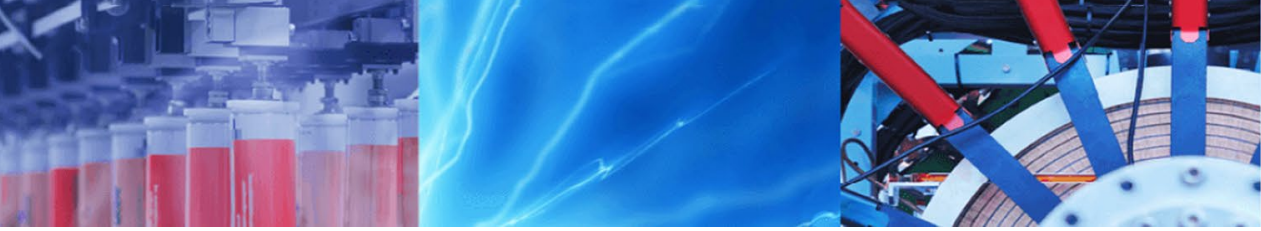

Research Article

\title{
Effect of enhanced weld cooling on the mechanical properties of a structural steel with a yield strength of $700 \mathrm{MPa}$
}

\author{
Juhani Laitila $^{1}$ - Lassi Keränen ${ }^{1}$ Jari Larkiola ${ }^{1}$
}

Received: 6 December 2019 / Accepted: 13 October 2020 / Published online: 26 October 2020

(C) The Author(s) 2020 OPEN

\begin{abstract}
In this study, we present the effect of enhanced cooling on the mechanical properties of a high-strength low-alloy steel (having a yield strength of $700 \mathrm{MPa}$ ) following a single-pass weld process. The properties evaluated in this study include uniform elongation, impact toughness, yield, tensile and fatigue strengths alongside the cooling time of the weld. With the steel used in this study, the enhanced cooling resulted in a weld joint characterized with excellent cross-weld uniform elongation, yield and fatigue strength. The intensified cooling reduced the time it takes for the weld to reach $100^{\circ} \mathrm{C}$ by around $190 \mathrm{~s}$. Not only the fusion line of the weld was less pronounced, but also the grain size of the CGHAZ was greatly refined as a result of the enhanced cooling. The results indicate that combining external cooling to the welding processes can be beneficial for the studied high-strength steel.
\end{abstract}

Keywords Arc welding $\cdot$ Bainite $\cdot$ Cooling time $\cdot$ Fatigue $\cdot$ GMAW $\cdot$ HAZ

\section{Introduction}

As the world is trying to reduce $\mathrm{CO}_{2}$ emissions, the demand for lightweight structures is increasing steadily. In this context, high-strength (HSS) and ultrahigh-strength (UHSS) steels have become an option to reduce the weight of the structures both in the vehicles as well as the construction industry. In addition, material costs are usually reduced, because the higher strength allows thinner wall thicknesses [1-4].

The heat-affected zone (HAZ) that is caused by the welding process, usually has inferior mechanical properties compared to base material. When welds are allowed to cool freely, the heat input together with joint size, geometry and the working temperature determine the cooling rate, which dictates the microstructure and properties of the HAZ [5]. Particularly in UHSS and HSS, the inferior properties of the HAZ are significant, because the thermal cycle experienced by the HAZ results in a loss of the beneficial thermomechanically processed microstructure of the base plate.

In applications that undergo dynamic loading, the fatigue limit of the steel is important, as fatigue is often the reason why the structure fails [6, 7]. However, the fatigue life of a welded structure depends such factors as weld geometry, residual stresses and inclusions. Fatigue strength is also relatively independent from yield strength when welded structures are observed and this makes forecasting the fatigue strength more difficult [8]. Determining fatigue strength is a time-consuming process, especially if high-cycle life is to be studied and less data is available on fatigue strength than on tensile and toughness properties.

To maximize the mechanical properties in the post-weld condition steel producers usually provide recommended cooling times for the weld to cool from 800 to $500^{\circ} \mathrm{C}$ (t8/5) $[1,4]$. Usually most of the microstructural changes in the $\mathrm{HAZ}$ take place in temperatures above $500^{\circ} \mathrm{C}$ [9]. For UHSS and HSS the recommended value of $\mathrm{t} 8 / 5$ is often between

Juhani Laitila, Juhani.Laitila@Oulu.fi; Lassi Keränen, lassi-pekka.keranen@oulu.fi; Jari Larkiola, Jari.Larkiola@Oulu.fi|'aterials and Production Engineering, Faculty of Technology, University of Oulu, Pentti Kaiteran Katu 1, 90570 Oulu, Finland. 
1 and $20 \mathrm{~s}[1,4]$. However, with bainitic or martensitic steels that have high tensile strengths, the cooling rate in temperatures below $500{ }^{\circ} \mathrm{C}$ does have an effect on the microstructure and thus the mechanical properties [10, 11]. For example, both lower bainite and martensite form in temperatures below $500{ }^{\circ} \mathrm{C}$ and both of these microstructures have good tensile strength properties. In addition, lower bainite has good impact toughness properties [12-14].

Another factor that needs to be considered when evaluating weld quality is the effect of residual stresses that are the result of the differing thermal cycles across the weld and HAZ. Residual stresses can have a negative side effect on the mechanical properties of the welded joint and especially on the fatigue strength. Besides, stresses influence in distortions and corrosion resistance $[15,16]$.

As the cooling rates have to be high to achieve good weld quality, the heat input has to be limited which often leads to use multipass welding. This consumes a lot of time due to the time needed for the joint to cool down to the required temperature before the next weld pass can be made. The maximum interpass temperature usually is limited to $100^{\circ} \mathrm{C}$, because of the effect it has on the maximum allowed heat input for the next weld pass. $[1,4,17,18]$.

The purpose of this work is (1) to establish the extent to which external cooling affects the mechanical properties of a single pass welded high-strength steel and especially the fatigue strength, (2) to determine the efficiency of the heat sinks in limiting the heating of the steel to the weld region, and (3) to determine the time saved by the heat sinks for an interpass temperature of $100^{\circ} \mathrm{C}$.

This paper has been divided into experimental procedures in which the methods used in the study are explained. The results of the experiments are presented in the following sub-categories: cooling rates and times, impact toughness, strength, fatigue strength and microstructure. In each category the results are reported and their statistical significance is evaluated. In the microstructure section the microstructure of the CGHAZ is briefly analyzed and discussed. Following the results section main findings have been summarized in the conclusions section with few suggestions for the future research.

\section{Experimental procedures}

The experimental part of the research was carried out with same welding and mechanical testing facilities as the authors used in previous study. However, the previous study focused on different steel and different welding parameters. In this study, single-pass welding was used and the design of the heat sinks was improved.
Furthermore, the previous study did not include any fatigue strength tests [19].

The experimental part of the research was based on eight welding experiments carried out with a Kemppi Pro MIG 500 and a Motoman-yasnac RX robot. Four of the eight welding runs were done with heat sinks that were placed $1 \mathrm{~mm}$ away from the edge of the weld seam, as shown in Fig. 1 and the other four were welded without any external cooling.

The material used in the welding experiments was a $6 \mathrm{~mm}$ thick commercial grade high-strength steel, with a minimum specified yield strength $\left(R_{p 0.2}\right)$ of $700 \mathrm{MPa}$, a tensile strength $\left(R_{m}\right)$ in the range $750-950 \mathrm{MPa}$, an elongation to fracture $\left(A_{5}\right)$ of at least $13 \%$ and a specified minimum impact strength of $40 \mathrm{~J}$ at $-60^{\circ} \mathrm{C}$ using Charpy $\mathrm{V}$ specimens aligned in the rolling direction [19]. The chemical composition of the steel as given by the manufacturer is shown in Table 1. The manufacturer's recommended cooling time t $8 / 5$ for the steel is from 1 to $20 \mathrm{~s}$, maximum heat input of about $0.9 \mathrm{~kJ} / \mathrm{mm}$ and maximum interpass temperature of $100^{\circ} \mathrm{C}$ [4].

The plates that were welded had dimensions of $400 \times 120 \times 6 \mathrm{~mm}, 400 \mathrm{~mm}$ being the length of the weld, and the weld preparation comprised a V-joint with an angle of 50 degrees. The temperature of the weld was measured at the middle of the weld length. The type of thermocouple used was K20-2-350 which has a maximum temperature limit of $1200^{\circ} \mathrm{C}$ The frequency used in the temperature measurement was $10 \mathrm{~Hz}$. Two more thermocouples were used to monitor the temperature of the plate being welded. A second thermocouple was positioned $5-10 \mathrm{~mm}$ from the outer edge of the plate at midlength and the third one was about $85-90 \mathrm{~mm}$ from the weld seam, also at the mid-length position, see Fig. 2 . The thermocouple that is positioned directly on the weld was attached to the weld about $35 \mathrm{~s}$ after the weld torch had been turned off with a five second error margin. The other

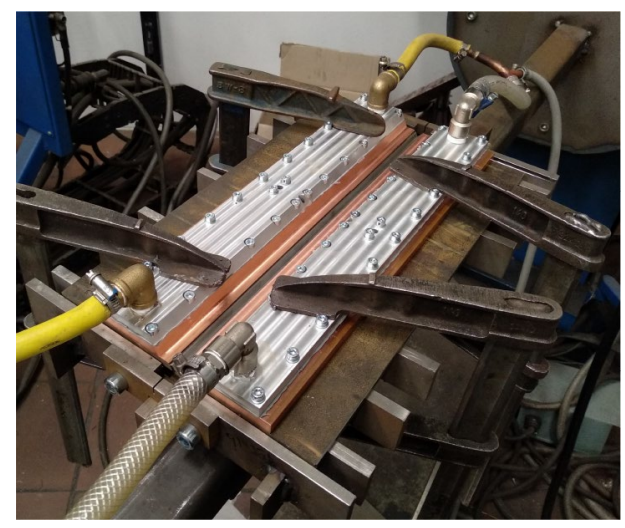

Fig. 1 Heat sinks on the steel plates 
Table 1 Chemical composition of steel (wt.\% max except Al) [20]

\begin{tabular}{lllllllll}
\hline $\mathrm{C}$ & $\mathrm{Si}$ & $\mathrm{Mn}$ & $\mathrm{P}$ & $\mathrm{S}$ & $\mathrm{Al}(\min \%)$ & $\mathrm{Nb}$ & $\mathrm{V}$ & $\mathrm{Ti}$ \\
\hline 0.12 & 0.25 & 2.10 & 0.020 & 0.010 & 0.015 & 0.09 & 0.20 & 0.15 \\
\hline
\end{tabular}

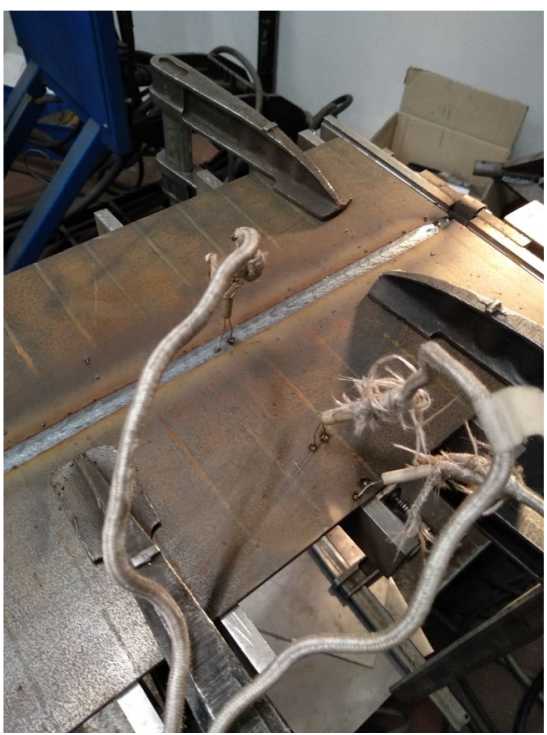

Fig. 2 Welded joint with all of the thermocouples attached

two thermocouples that were connected to the plate itself were connected before welding began.

The orientation of the welds was such that cross-weld tensile strength, fatigue strength and Charpy V-notch specimens were transverse to the rolling direction. Originally two tensile, two impact and eight fatigue strength specimens were taken from each weld, but some specimens were unusable due to surface defects. All the specimens were taken between 50 and $350 \mathrm{~mm}$ along the length of the weld in order to minimize cooling time differences that would result otherwise due to end effects. For tensile strength experiments five specimens were used for the normal and four for the cooled series. In the case of impact strength, five specimens were used for each series. In fatigue strength tests 17 normal specimens and 13 cooled specimens were used initially. Three fatigue strength samples that did not break within 10 million cycles, were reused from both series following the idea of the locati method [21].

All the specimens were cut and machined from the middle of the plate depth wise and in a way that the center of the weld was the center of the tensile and fatigue strength specimens length wise. In the case of Charpy specimens, etching was used to reveal the location of the fusion line and after that they were machined to their final dimension to ensure that the V-notch was placed such that the middle of the notch was on the fusion line. The Charpy
Table 2 Welding parameters

\begin{tabular}{ll}
\hline Parameter & Value \\
\hline Current $(\mathrm{I})$ & $220 \mathrm{~A}$ \\
Voltage $(\mathrm{U})$ & $22.2 \mathrm{~V}$ \\
Travel speed $(\mathrm{v})$ & $320 \mathrm{~mm} / \mathrm{min}$ \\
Angle of the weld torch & 17 \\
Welding wire & Aristorod $69(\varnothing 1.2 \mathrm{~mm})$ \\
Arc energy (E) & $0.92 \mathrm{~kJ} / \mathrm{mm}$ \\
Heat input (Q) & $0.73 \mathrm{~kJ} / \mathrm{mm}$ \\
Gas flow rate & $18 \mathrm{I} / \mathrm{min}(75 \% \mathrm{Ar}+25 \%$ \\
& $\left.\mathrm{CO}_{2}+0.03 \% \mathrm{NO}\right)$ \\
Preheating temperature & $21 \mathrm{C}$ \\
\hline
\end{tabular}

specimens used in the experiment were sub-sized with dimensions of $55 \times 10 \times 5 \mathrm{~mm}$ with tolerances as given in the standard EN 100,045-1. The same standard was followed for the impact strength testing at $-40^{\circ} \mathrm{C}$.

Cross-weld tensile testing was made using $3 \mathrm{~mm}$ thick flat specimens that were obtained from the $6 \mathrm{~mm}$ thick welded sheets by milling away $1.5 \mathrm{~mm}$ from both face and root sides of the weld. The specimens had a width of $12 \mathrm{~mm}$ in the $75 \mathrm{~mm}$ long reduced section with the weld at its middle. The gauge length used was $50 \mathrm{~mm}$.

The fatigue specimen dimensions for the high-cycle life tests followed the ASTM E 466 standard. The specimens had a thickness of $3 \mathrm{~mm}$, a nominal width of $8 \mathrm{~mm}$, a uniform length of $20 \mathrm{~mm}$, and the total width of the specimen was $20 \mathrm{~mm}$, and $R$ was $25 \mathrm{~mm}$. The specimens were ground with sandpaper that had an ISO grit of P1200 to limit the variation in surface roughness.

Both series, cooled and normal, were done with the same welding program. The parameters that were used in the experiment are shown on the Table 2. The contact area of the cooling block was made from $\mathrm{C} 110$ copper and the top of the cooling block was made from aluminum. The dimensions of the cooling blocks can be seen in Fig. 3 and Table 3 along with the water flow and temperature parameters.

Metallographic specimens were taken from the welds to study the grain size in coarse grained heat-affected zone (CGHAZ) and the fusion line, these samples were etched with $0.2 \%$ nital. Micrographs were taken using light optical microscopy and software was used to calculate the grain sizes from the images using the linear intercept method. All of the images were taken at about the depth of $3 \mathrm{~mm}$ from top of the weld. 
Fig. 3 External dimensions of the cooling blocks
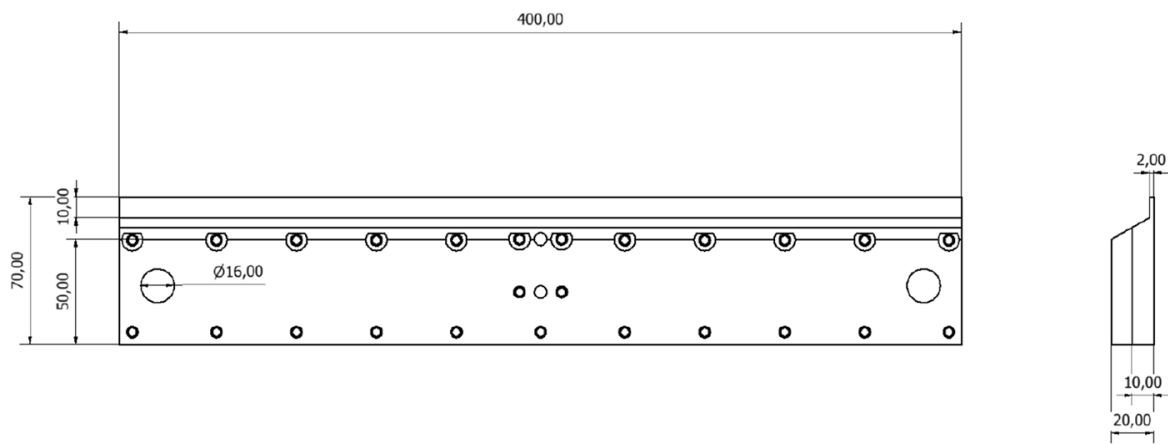

Table 3 Cooling block parameters

\begin{tabular}{ll}
\hline Parameter & Value \\
\hline block length (I) & $400 \mathrm{~mm}$ \\
block width (w) & $70 \mathrm{~mm}$ \\
block height (h) & $20 \mathrm{~mm}$ \\
Water flow (v) & $6 \mathrm{l} / \mathrm{min}$ \\
Water temperature (T) & $4{ }^{\circ} \mathrm{C}$ \\
Distance from weld & $1 \mathrm{~mm}$ \\
\hline
\end{tabular}

\section{Results \& discussion}

\subsection{Cooling rates and times}

The weld had cooled down to temperatures around $90^{\circ} \mathrm{C}$ before the thermocouple was attached to the weld itself when the external cooling was used. This means that it took the weld less than $40 \mathrm{~s}$ to cool down to temperatures below $100{ }^{\circ} \mathrm{C}$ given the $30-40 \mathrm{~s}$ timeframe from the time when the weld torch turned off to the time when the thermocouple was attached to the weld seam. Furthermore, the weld continued to cool down with an average cooling rate of $1.23^{\circ} \mathrm{C} / \mathrm{s}$ over the temperature range $90-50{ }^{\circ} \mathrm{C}$. The thermocouples connected to the plate away from the weld seam only experienced temperature increases of around $3-5^{\circ} \mathrm{C}$.

The welds without external cooling only cooled to $230^{\circ} \mathrm{C}$ by the time the thermocouple was connected. The average cooling rates achieved over the range $230-50{ }^{\circ} \mathrm{C}$ can be seen in Fig. 4. The time it took for the weld to cool to $100{ }^{\circ} \mathrm{C}$ from the time when the weld arc was turned off was on average $244 \mathrm{~s}$ when $35 \mathrm{~s}$ is used as the time it took to connect the thermocouple to the weld after the arc was turned off. The thermocouple that was attached to the plate about $85 \mathrm{~mm}$ from the edge of the weld recorded on average a maximum temperature of $79{ }^{\circ} \mathrm{C}$ and the one next to the edge of the plate experienced peak temperature of $68^{\circ} \mathrm{C}$ on average. Furthermore, the

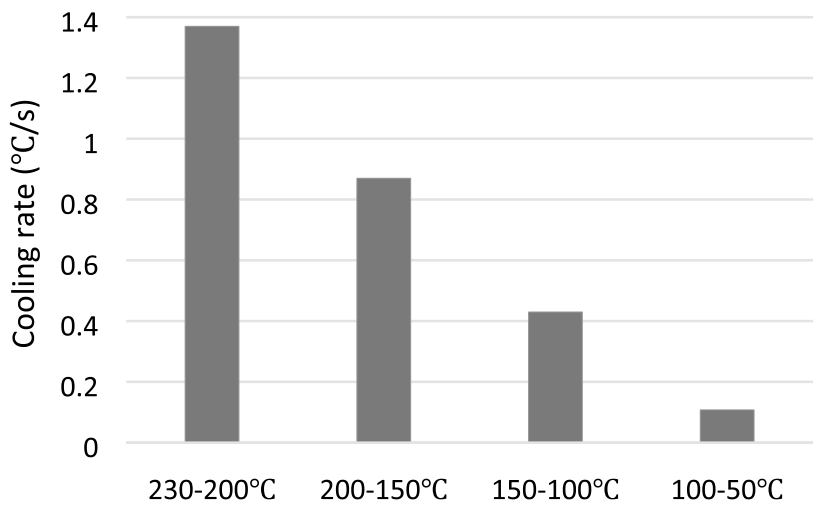

Fig. 4 Median cooling rates for welds without external cooling

temperatures measured at the weld and the other two thermocouples became equal at around $50^{\circ} \mathrm{C}$.

Therefore, the total time saved on average was at least $200 \mathrm{~s}$ with the parameters used when the time it takes for the weld to reach $100{ }^{\circ} \mathrm{C}$ was considered. This could lead to significant time savings in a multipass welding process. Another possible benefit is a reduction in the interpass temperature which would lead to higher acceptable heat inputs for the following weld passes. As the heat input and the material deposition rates correlate with each other, the use of higher heat input would allow higher material deposition rates, which can translate into a reduction of the total number of weld passes needed to complete the weld. As every weld pass produces a local brittle zone (LBZ), it is highly desirable to minimize the amount of weld passes not only from the process time point of view but from the material properties point of view as well [22].

\subsection{Impact toughness}

The median impact toughness can be seen on the Fig. 5 . However, there differences in impact toughness results were not statistically significant with confidence interval of $95 \%$ after the removal of one outlier specimen $(P$-value $>>0.05)$. One of the normal specimens had impact toughness of $61 \mathrm{~J}$, which is a clear outlier and can 
be explained with transition temperature that is most likely around $-40{ }^{\circ} \mathrm{C}$ in this case. The specimens tended to present a fairly brittle fracture surface when evaluated visually according to ISO 148-1. The average ductile fracture percentage observed was $49 \%$ for the normal specimens and $40 \%$ for the cooled specimens, however, the difference was not statistically significant. This means that it is very likely that the cooling does not have a significant effect on the impact toughness of the weld.

\subsection{Strength}

Tensile and yield strengths increased significantly when the external cooling was applied as shown in Fig. 6 and the increase was statistically significant at the $95 \%$ confidence level. The elongation to fracture improved as well with the external cooling. Similar results were observed in an earlier study in which forced weld cooling of a $700 \mathrm{MPa}$ grade steel was simulated with a Gleeble [10]. The improvement of the uniform elongation was statistically significant at the $95 \%$ confidence level, as can be seen from Fig. 7 . However, the magnitude of the uniform elongation is very small $(<2 \%)$, so the improvement in uniform elongation was practically insignificant from a usability point of view. Furthermore, all specimens failed in the HAZ, except one normal specimen that failed in the fusion line.

\subsection{Fatigue}

Based on the results of the fatigue experiments, the cooled samples seemed to have an overall higher fatigue strength, as can be seen from Fig. 8. Jiang et al. [15] found that external cooling provided by a copper heat sink placed under the weld reduced residual stresses by $20 \%$. As residual stress is known to have an effect on the fatigue strength of steel, the increased fatigue strength might be

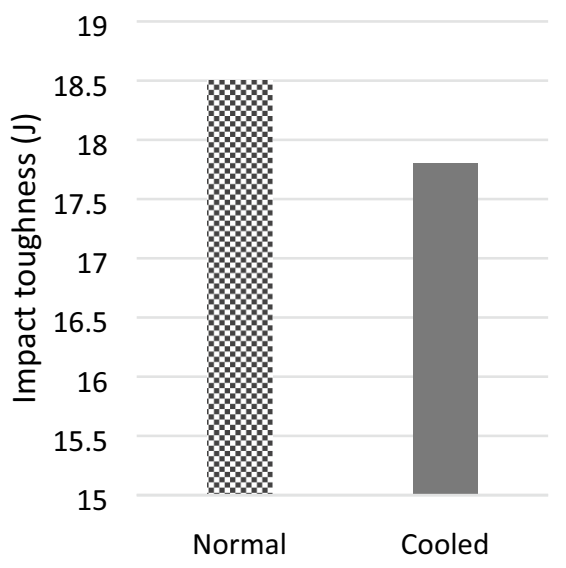

Fig. 5 Median Charpy V impact toughness at $-40^{\circ} \mathrm{C}$

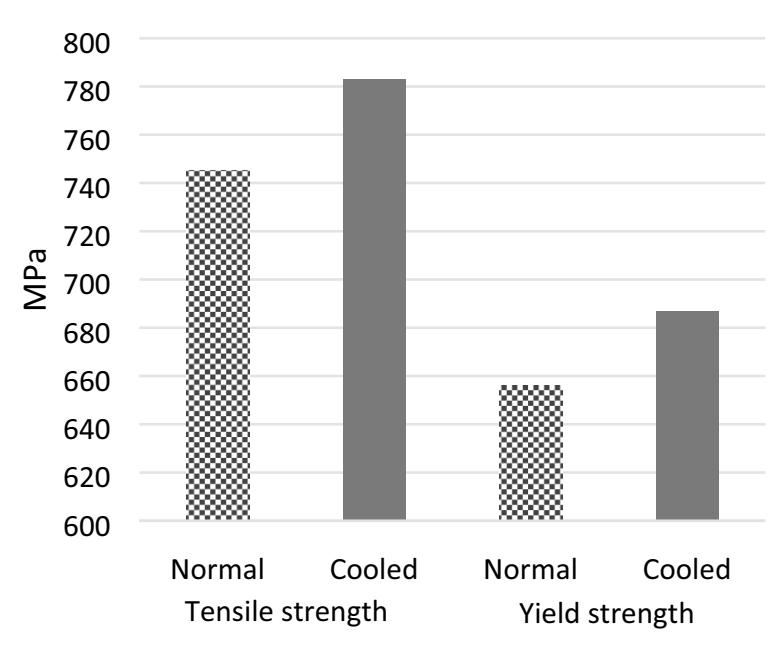

Fig. 6 Median cross-weld tensile and yield strengths

due to reduced residual stresses in the cooled samples. However, other aspects such as microstructure and grain size can affect the fatigue strength as well. In the case of fatigue strength specimens, the cracks propagated at the fusion line.

In the locati method tests, it was observed that the median fatigue limit of both normal and cooled specimens was about the same without any statistical difference between cooled and non-cooled series. The median fatigue limit for cooled specimens was $650 \mathrm{MPa}$ and normal specimens $645 \mathrm{MPa}$. If the fatigue tests before the locati method runs will have already eliminated the original residual stresses, it is possible that the differences in the original fatigue test results are indeed caused by the residual stress differences. However, as the specimens studied were machined and ground with sandpaper the results cannot be compared to that of the welds without any post-weld treatments, as they have lower fatigue strength due to surface imperfections, weld toe and other

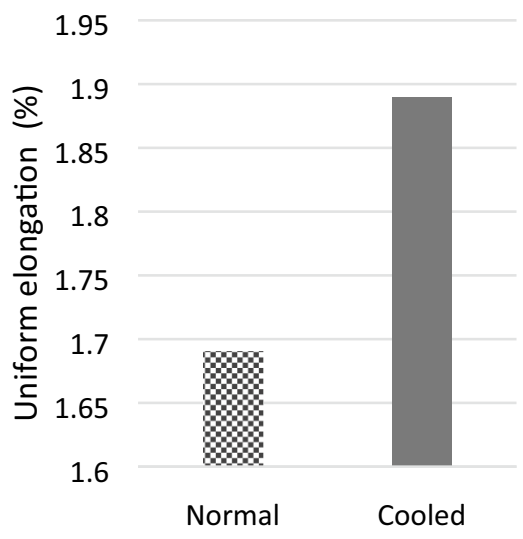

Fig. 7 Median uniform elongation 
important factors. In addition, machining the specimens after the weld can release some of the residual stresses, but this was not studied. Furthermore, the increased yield and tensile strengths of the cooled specimens can lead to increased fatigue limit as well. As the question of whether the fatigue limit is affected by the cooling and if so, what is the causation behind it, still remains. Further studies should be done about the effect of the external cooling on the fatigue strength of the steel, especially with specimens that still contain residual stresses.

\subsection{Microstructure}

The most significant difference between welds that were welded with and without external cooling was the effect that the external cooling had on the fusion line of the weld. The fusion line is not as clear on the welds with external cooling as on the normal welds as can be seen on Fig. 9. This means that the external cooling had an effect on the liquid metal flow, which, in turn, had an effect on the fusion process.

When grain size was calculated from the area that can be seen in Fig. 10 by using linear intercept method, the median grain size was reduced from 56.8 to $50.7 \mu \mathrm{m}$ when the external cooling was used. The microstructure appears to have a more lath like microstructure when external cooling is used. As the refined grain size does not seem to have a negative effect on the uniform elongation, the lath like structure could be lower bainite as it has better elongation properties than martensite and unlike upper bainite it forms at temperatures below $440^{\circ} \mathrm{C}$ [12-14]. This is further backed by the observation of increased tensile and yield
Fig. 8 Fatigue results for the cooled and non-cooled weld
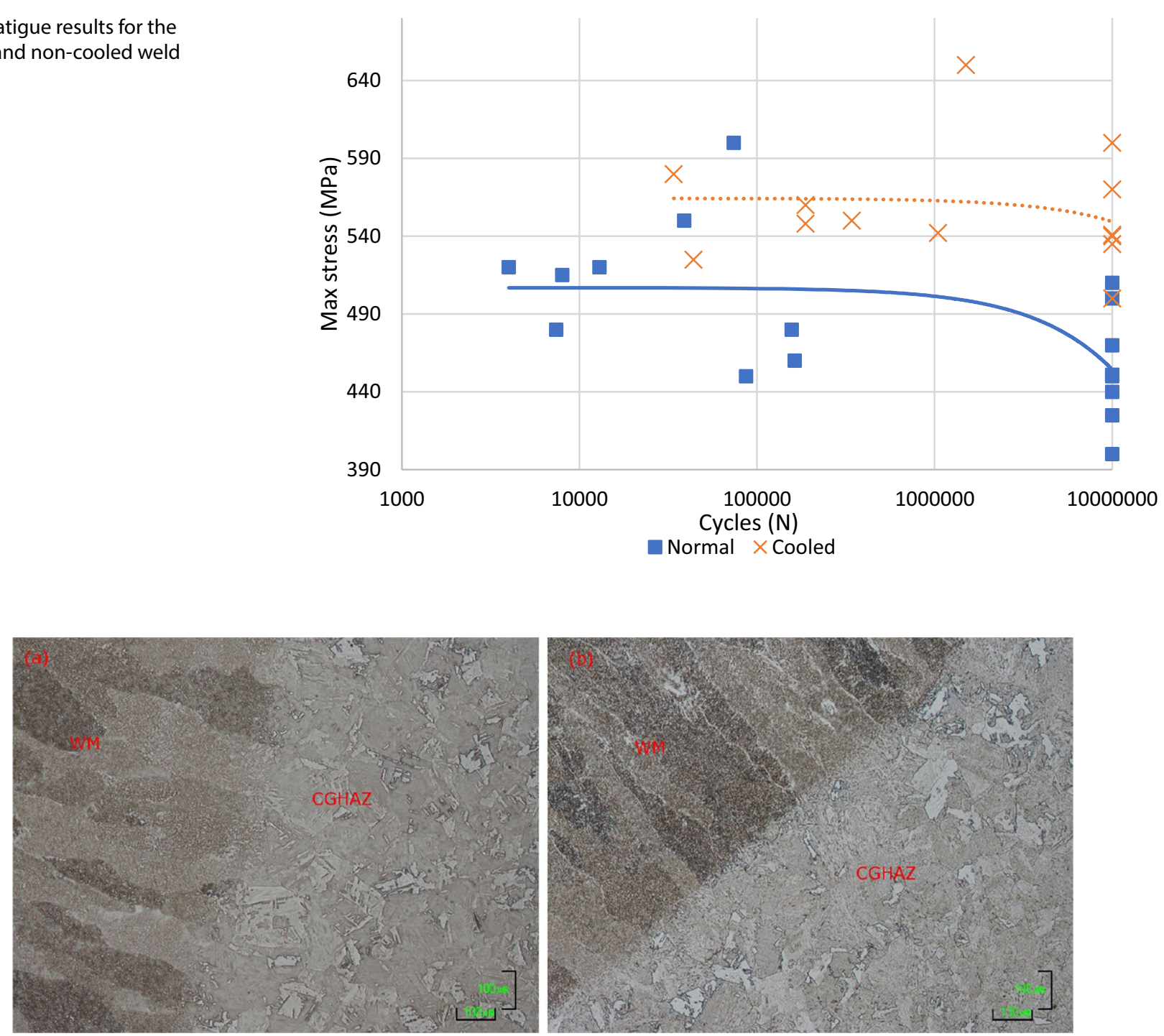

Fig. 9 Fusion line images a cooled, b normal 

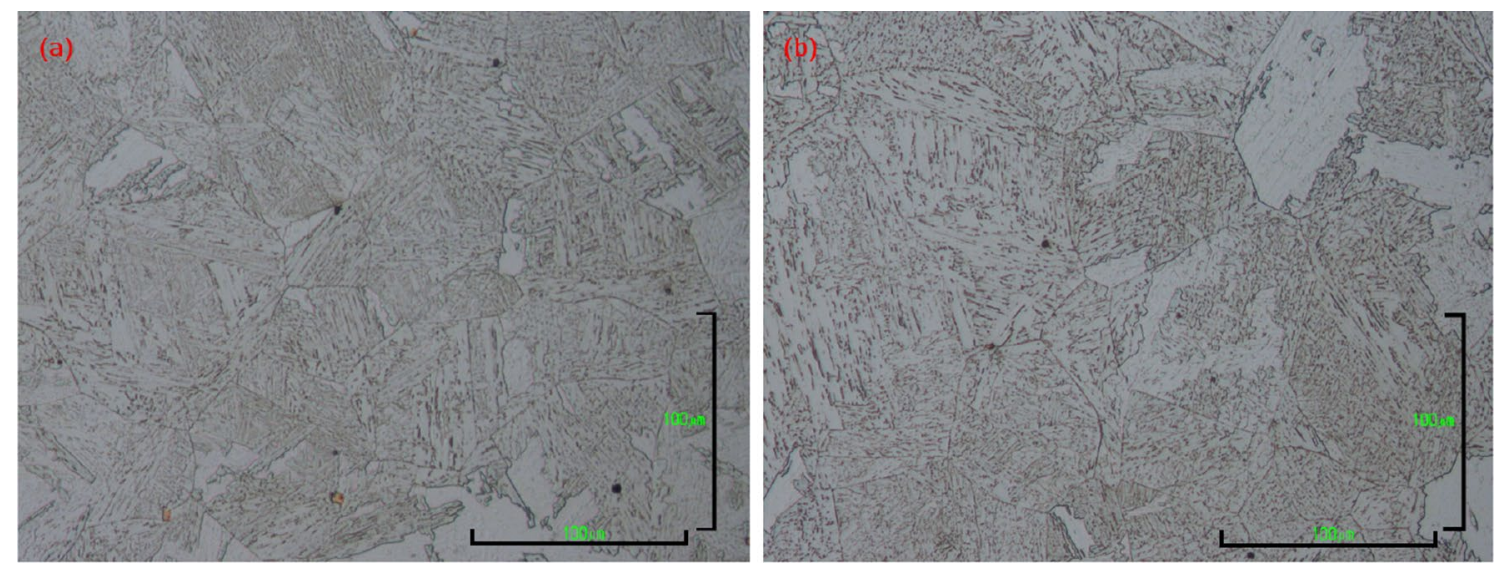

Fig. 10 CGHAZ images of the specimens a cooled, $\mathbf{b}$ normal

strength, which can be explained with finer grain size or by many other factors such as by having larger quantities of bainite or martensite as result of the cooling. However, larger quantity of martensite would cause the steel to be less ductile.

\section{Conclusions}

This study presents the effect of enhanced cooling on the mechanical properties of a $6 \mathrm{~mm}$ thick commercial grade steel (yield strength-700 MPa) single-pass welded using a heat input of $0.73 \mathrm{~kJ} / \mathrm{mm}$. The effect of the enhanced cooling on the cooling time and the capacity of the heat sinks to eliminate the temperature rise outside of the weld region was studied as well. The joint that had cooling applied to it showed superior uniform elongation, yield and fatigue strengths, whereas the impact toughness and tensile strength of the steel remained unchanged. The time taken for the weld to cool down to $100^{\circ} \mathrm{C}$ was reduced by $190 \mathrm{~s}$ with the enhanced cooling. The heat sinks used to cool the weld also limited the rise in temperature of the weld region nearly completely (only about $3-5^{\circ} \mathrm{C}$ outside of the weld region).

In multipass welding processes the interpass temperature is often $100{ }^{\circ} \mathrm{C}$, which means that applying the heat sink based cooling to the process could lead to significant time savings without any detrimental effect on the welded joint itself.

In this study it was found that the enhanced cooling caused changes to the fusion line of the weld. However, the exact reason for the occurrence of this phenomena remains unclear and should be researched further. The role of enhanced cooling on the internal stress should be studied as well.
Funding Open access funding provided by University of Oulu including Oulu University Hospital. This study was funded by Business Finland.

\section{Compliance with ethical standards}

Conflict of interest The authors declare that they have no conflict of interest.

Open Access This article is licensed under a Creative Commons Attribution 4.0 International License, which permits use, sharing, adaptation, distribution and reproduction in any medium or format, as long as you give appropriate credit to the original author(s) and the source, provide a link to the Creative Commons licence, and indicate if changes were made. The images or other third party material in this article are included in the article's Creative Commons licence, unless indicated otherwise in a credit line to the material. If material is not included in the article's Creative Commons licence and your intended use is not permitted by statutory regulation or exceeds the permitted use, you will need to obtain permission directly from the copyright holder. To view a copy of this licence, visit http://creativecommons .org/licenses/by/4.0/.

\section{References}

1. ArcelorMittal, Amstrong Ultra-Ultra High Strength Steels, https ://industry.arcelormittal.com/catalogue/A22/EN. Accessed 29 Aug 2019

2. Javidan F, Heidarpour A, Zhao X-L et al (2016) Effect of weld on the mechanical properties of high strength and ultra-high strength steel tubes in fabricated hybrid sections. Eng Struct 118:16-27. https://doi.org/10.1016/j.engstruct.2016.03.046

3. Qiang X, Jiang X, Bijlaard FS, Kolstein H (2016) Mechanical properties and design recommendations of very high strength steel s960 in fire. Eng Struct 112:60-70. https://doi.org/10.1016/j. engstruct.2016.01.008

4. SSAB,Welding of strenx, https://www.ssab.com/products/brand s/strenx/products/strenx-700-mc-plus?accordion=workshop. Accessed 29 Aug 2019 
5. Hart PHM (2003) The influence of vanadium-microalloying on the weldability of steels. Weld Cut 55(4):204-210

6. Chapetti MD, Jaureguizahar LF (2012) Fatigue behavior prediction of welded joints by using an integrated fracture mechanics approach. Int J Fatigue 43:43-53. https://doi.org/10.1016/j.ijfat igue.2012.02.004

7. Björk T, Samuelsson J, Marquis G (2008) The need for a weld quality system for fatigue loaded structures. Weld World 52:3446. https://doi.org/10.1007/bf03266615

8. Hobbacher A (2007) Recommendations for fatigue design of welded joints and components. International Institute of Welding, doc. XIII-2151-07/XV-1254-07. Paris, France, May

9. S. Endo, N. Ishikawa, J. Kondo, N. Suzuki, K. Omata (2002) Advance in high performance linepipes with respect to strength and deformability In: Proceeding of the International Conference Pipe Dreamer's Conference, Yokohama, Japan, pp. 7-8

10. Laitila J, Larkiola J, Porter D (2017) Effect of forced cooling on the tensile properties and impact toughness of the coarse-grained heat-affected zone of a high-strength structural steel. Weld World 62:79-85. https://doi.org/10.1007/s40194-017-0532-z

11. Laitila J, Larkiola J, Porter D (2018) Effect of forced cooling after welding on CGHAZ mechanical properties of a martensitic steel. Weld World. https://doi.org/10.1007/s40194-018-0617-3

12. Chang LC, Bhadeshia HKDH (1996) Microstructure of lower bainite formed at large undercoolings below bainite start temperature. Mater Sci Technol 12:233-236. https://doi. org/10.1179/026708396790165687

13. Bhadeshia HKDH (2001) Bainite in steels: transformations, microstructure and properties. IOM Communications, London

14. Verhoeven JD (2007) Steel metallurgy for the non-metallurgist. ASM International, Materials Park, OH

15. Jiang W, Zhang Y, Woo W (2012) Using heat sink technology to decrease residual stress in $316 \mathrm{~L}$ stainless steel welding joint: finite element simulation. Int J Press Vessels Pip 92:56-62. https ://doi.org/10.1016/j.ijpvp.2012.01.002
16. Jenney CL, O'Brien A (1991) Welding Handbook. American Welding Society, Miami

17. Wang XL, Tsai YT, Yang JR et al (2017) Effect of interpass temperature on the microstructure and mechanical properties of multi-pass weld metal in a 550-MPa-grade offshore engineering steel. Weld World 61:1155-1168. https://doi.org/10.1007/s4019 4-017-0498-X

18. Peng Y, Wang AH, Xiao HJ, Tian ZL (2012) Effect of Interpass temperature on microstructure and mechanical properties of weld metal of 690 MPa HSLA steel. Mater Sci Forum 706709:2246-2252. https://doi.org/10.4028/www.scientific.net/ msf.706-709.2246

19. Laitila J, Larkiola J (2019) Effect of enhanced cooling on mechanical properties of a multipass welded martensitic steel. Weld World 63:637-646. https://doi.org/10.1007/s40194-018-00689 $-7$

20. SSAB, Strenx 700 MC Plus, https://www.ssab.com/products/ brands/strenx/products/strenx-700-mc-plus. Accessed 29 Aug 2019

21. Rabb R (2017) Väsyminen ja todennäköisyysteoria. University of Oulu, Finland

22. Jang J-I, Lee B-W, Ju J-B et al (2003) Experimental analysis of the practical LBZ effects on the brittle fracture performance of cryogenic steel HAZs with respect to crack arrest toughness near fusion line. Eng Fract Mech 70:1245-1257. https://doi. org/10.1016/S0013-7944(02)00111-X

Publisher's Note Springer Nature remains neutral with regard to jurisdictional claims in published maps and institutional affiliations. 